\title{
The relationship between organizational justice and nurses' productivity at Menoufia University Hospitals
}

\author{
Zeinab M. Abu Auf ${ }^{1}$, Manal Mohamed Bakr ${ }^{2}$, and Nabila Mahmoud \\ Shrief $^{3}$ \\ ${ }^{1}$ B.Sc. Nursing Science (nursing administration), ${ }^{2}$ Assistant Professor of \\ Nursing Administration, ${ }^{3}$ Lecturer of Nursing Administration, Faculty of \\ Nursing, Menoufia University ${ }^{23}$
}

\begin{abstract}
Background: Organizational justice is one of the factors that may affect nurses' productivity. Justice is the key to the survival and sustenance of growth and development in the nurses and organization. purpose: The purpose of the study was to identify the relationship between organizational justice and nurses' productivity. Research design: A descriptive correlational design was used. Setting: The study was conducted at at Shebin ElKom Menoufia University Hospitals. Sample 300 staff nurses were included in the study. Instruments: Data were collected by using organizational justice questionnaire and productivity questionnaire. Results: more than half (58\%) of staff nurses had low level of organizational justice, slightly more than three quarter (76\%) of staff nurses had low level of nurses' productivity. Recommendations: Nurses mangers must provide a safe work environment and team trust to deliver healthcare effectively for better patient outcomes. training program must be developed for staff nurses to improve their knowledge, skills, and attitude toward organizational justice and nurses' productivity.
\end{abstract}

Key Words: Organizational justice, Staff nurses, productivity.

\section{Introduction:}

How nurses determine if they have been treated fairly in their jobs and how those determinations influence other workrelated variables. Organizational justice can help explain why nurses retaliate against inequitable outcomes or inappropriate processes and interactions (Al-Zu'bi, 2010).

Justice in the organization would include perceptions related to pay, opportunities for promotion, and nurse selection procedures. Nurses who perceive fair treatment from the organization tend to develop and maintain relationships with the organization. However, perceptions of injustice can impact job attitudes and work behaviors. When an employee perceives they are being treated unfairly by the organization they will likely behave in a counter-productive manner that can result in lower nurses' productivity and performance (Davis, 2015).

Organizational justice as is referring to the extent to which nurses perceive workplace procedure, interaction, and outcomes to be fair. These perceptions can influence attitudes and behavior for good or bad which in turn will have an impact on nurses' productivity, commitment, and organizational success (Ajala, 2015).

It is generally divided into three aspects: distributive, procedural, and interactional justice. Some scholars approach organizational justice as comprising only distributive and procedural justice. While other scholars regard interactional justice as a sub-aspects of distributive 


\section{The relationship between organizational justice and nurses' productivity at Menoufia University Hospitals}

justice (Suliman, \& Kathairi, 2013). Yet other scholars see four factors, dividing interactional justice into the subdimensions of interpersonal and informational justice (Crawshaw, et al., 2013).

Distributive justice refers to the concerns of staff regarding resource and consequence distribution and demonstrates the individual's perception of the degree of justice in distributing and allocating resources and rewards. It focuses on wage increases, performance evaluations, promotions, and punishments (Azizollah, et al., 2014).

Procedural justice is how individuals perceive the decision that had been made according to the organization systems and from the treatment given by the organization in enforcing those decisions. The concept of procedural justice hinges on an individual's assessment about rightness or wrongness of procedures and methods in the decision making relevant to him or others (Krishnan, et al., 2018).

Interactional justice actually divided into two parts, namely interpersonal justice and informational justice. Interpersonal justice is about to what extend courtesy, value, and respect, are shown towards the employees. Informational justice is the process of organization management regularly informing the nurses about the methods, procedures and policies used in determination and measurement of elements such as wages, promotion, financial facilities, working conditions and performance assessment (Demirkiran et al., 2016).

Productivity is basic to understanding the work-load needed to provide patient care at the bedside. In its simplest definition, it is defined as the measurement of the efficiency and amount of labor required to provide elements of nursing care. However, the consistency of productivity outcomes depends on the variables and the setting in which it is used (Lee, \& winters, 2018). Productivity in nursing is related to both efficiencies of the use of clinical nursing in delivering nursing care and the effectiveness of that care relative to its quality and appropriateness (Roussel, 2013).

Productivity does not guarantee the quality of patient care; it only indicates that the appropriate number of staff is available to provide patient care (Zoschak, 2010). Identified health challenges and needs include timely, poor human resource management, and poor productivity of health personnel resulting in the poor quality of services due to limited opportunities for career advancement and productivity reward systems. The importance of performance management in the health workforce is regarded as 'essential to improving efficiency, productivity, and quality of care (Awases, et al., 2013).

Organizational justice is one of the factors that may affect nurses' productivity. Justice is a sociallyembedded concept involved in most aspects of life. It is commonly held that justice should accompany the outcomes of every effort. Justice is also conceptualized within organizations, which is referred to as organizational justice. Fairness to nurses on the part of the organization typically results in their higher productivity and better citizenship behavior. On the other hand, those who feel they are exposed to injustice are more likely to leave the organization or to show lower levels of organizational 


\section{The relationship between organizational justice and nurses' productivity at Menoufia University Hospitals}

commitment and productivity (Doulati, \& Pour, 2017).

\section{Purpose of the Study}

Identify the relationship between organizational justice and nurses' productivity at Menoufia university hospitals.

\section{Research Questions:}

Is there a relationship between organizational justice and nurses' productivity at Menoufia university hospitals?

Which of the organizational justice aspects best predict nurses' productivity at Menoufia university hospitals?

\section{Methods}

\section{Study design}

Descriptive co-relational design was used to carry out this study.

\section{Sample}

Convenience sampling technique 300 staff nurses were working at selected Menoufia University hospitals.

\section{Setting}

This study was conducted at selected general and closed (critical care) units at Shebin El-Kom Menoufia University Hospitals

\section{Instruments}

\section{The first instrument contains two parts:}

Part 1: Socio-demographic data:

This part involved socio-demographic data of staff nurses. It included unit, gender, age, marital status, years of experience and education.
Part II: Organizational Justice:

This part concerned with questionnaire about organizational justice. Three aspects of organizational justice questionnaire were developed by Niehoff and Moorman (1993) Menoufia University Hospitals. These aspects included 20 items.

First aspect distributive justice included 5 items. Second aspect procedural justice included 6items.Third aspect interactional justice included 9 items. Five - points likert scale type was used for each statement .The scores of each group of items were summed-up and the total divided by the number of the items in this group, giving a mean score for each aspect of the organizational justice. These scores were converted into a mean percent score for high, medium or low.

\section{Instrument two:}

\section{Productivity Questionnaire:}

This instrument was developed by McNeese-Smith (1996).It was used to measure productivity. The questionnaire tool consists of 18 items each of them has its related question the total number of the question (74) related to productivity. The questionnaire scored on the basis of, if answered "Yes" scored (one point), and if answered "no" scored (zero). (High $=75-100 \%$, moderate $=60$ $74 \%$ poor $=$ less than $60 \%$ ).

\section{Pilot study}

The pilot study was carried out on thirty staff nurses; also they were excluded from the main study. The time required for each staff nurse, the staff was estimated to be 15-20 minutes.

\section{Ethical Consideration:}




\section{The relationship between organizational justice and nurses' productivity at Menoufia University Hospitals}

Written approval was obtained from ethical and research committee of the Faculty of Nursing, Menoufia University dated 9/1/2019. Written acceptance to share in the study was obtained from nurses.

\section{Procedure:}

Before any attempt to collect data, an official letter was submitted from the Dean of the Nursing College to collect data from the Pre-mentioned study settings, also a written approval letter was submitted to the director of Menoufia University Hospital. The letter contained the title, aim of the study, and methods of data collection. Data collection procedures, analysis, and reporting of findings were undertaken in a manner designed to protect the confidentiality of subjects.

\section{Validity and reliability:}

The validity of the questionnaires was assessed by using content validity by three experts in the administrative nursing department. The relevancy, clarity, fluency, and simplicity of each component in the questionnaires were examined by experts and they found the questionnaires were useful and helpful.

1. Organizational justice questionnaire: it was previously used in El-Bardan's (2011) study. This instrument was tested for reliability by the internal consistency coefficient alpha which was 0.9487 .

The 5 items were related to distributive justice (alpha value 0.8693), 6 items to procedural justice (alpha value 0.8974), and 9 items for interactional justice (alpha value 0.9449).

2. Productivity questionnaire tool: it was previously used in Nassar (2011) study. This instrument was tested to reliability by the internal consistency coefficient alpha (0.96) .

\section{Statistical design}

\section{Analysis of data}

Data entry was done using SPSS (Version22) quantitative data were expressed as mean and standard deviation and quantitative data were expressed as frequency and percentage .

Chi-Square test was used in this study to identify whether there are statistically significant differences between the responses of nurses in the sample for each item. One way ANOVA test was also used at this study for a variable that had more than two groups such as educational level, marital status, and years of experience. This test was used to describe phrases in the term of frequency, percentage, the mean and standard deviation of the variables .

Spearman`s test was used to find correlation between study variables $\mathrm{P}$ value considered high significance at $\mathrm{P}$ value $<0.001$, significant at $\mathrm{P}$-value $\leq 0.05$.

Table (1): according to their characteristics. In relation to their age, this table showed that more than half $(51.33 \%)$ of the studied nurses were between 20-30 years. In addition, more than half $(51.7 \%)$ of the studied nurses were working at the general department units (medical department, surgical department, pediatrics department, obstetrics department, outpatient clinics, emergency department), about threequarters of them were female. Regarding the marital status, the majority of the studied nurses $(83.3 \%)$ were married. According to their experience, the highest percentage of them $(31.7 \%)$ have 


\section{The relationship between organizational justice and nurses' productivity at Menoufia University Hospitals}

to experience between 1-5 years and finally, the majority of the studied nurses (46.3\%) had associated a degree in nursing.

Table (2): Showed that the grand mean and standard deviation of the organizational justice of the studied nurses were $(48.1 \pm 10.80)$. It also showed that the highest mean percentage $(49.18 \%)$ of studied nurses toward organizational justice was related to interactional justice, while the lowest mean justice and nurses' productivity ( $\mathrm{r}$ $=0.198, \mathrm{p}<0.01)$, and interactional justice and nurses' productivity $(\mathrm{r}=$ $0.221, \mathrm{p}<0.01$ ).

Table (3): showed that more than three quarter $(80.3 \%)$ of the studied nurses reported that not achieved regarding equipment and supplies followed by work condition $(8.3 \%)$, work motivation (78.3\%), goal attainment (76.7\%), development and advancement (74.0\%), initiative $(71.7 \%)$, quality of nursing services $(69.3 \%)$, decision making and problem-solving $(68.3 \%)$, physical work environment $(63.3 \%)$, nurse growth $(63.0 \%)$, and sick leaves $(58.0 \%)$.

While, in contrast, the highest percentage (89.7 \%) studied nurses' productivity was achieved and related to waste disposal. Also, approximately three-quarters of the studied nurses reported that achieved regarding social relation, work habits, new skills, work engagement, work effectiveness $(79.7 \%$, $73.7 \%, \quad 71.0 \%, \quad 70.4 \%, \quad 67.6 \%)$ respectively and more than half of the studied nurses (55.3\%) reported that achieved regarding work organization.

Table (4) shows the correlation among distributive, procedural, interactional justice and nurses' productivity. The table clarified that significant positive correlations were found between distributive justice and nurses' productivity $(\mathrm{r}=0.168, \mathrm{p}<0.01)$, procedural justice and nurses' productivity $(\mathrm{r}=0.198, \mathrm{p}<0.01)$, and interactional justice and nurses' productivity $(\mathrm{r}=0.221, \mathrm{p}<0.01)$.

Table (5): Shows the correlation between organizational justice and nurses' productivity of the studied nurses. It clarified that there was a highly positive statistically significant correlation between organizational justice and nurses' productivity.

Table (6): shows the significant effect of each independent variable towards the dependent variable. From the table, interactional justice has the strongest effect $(\mathrm{p}=0.000)$ and a highly significant contributor to nurses' productivity $(\mathrm{B}=0.326, \mathrm{t}=3.921, \mathrm{p}<0.05)$. Meanwhile, procedural justice $(\mathrm{p}=001, \mathrm{t}=3.478$, $\mathrm{p}<0.05)$ and distributive justice $(\mathrm{p}=0.03$, $\mathrm{t}=2.948 \quad \mathrm{p}<0.05)$ both show the significant relationship towards nurses' productivity

Figure (1): illustrated that more than half of the studied nurses $(58 \%)$ had a low level of organizational justice, $(41 \%)$ had a moderate level of organizational justice and $(1 \%)$ had a high level of organizational justice.

Figure (2): illustrated that three-quarters of the studied nurses had a low level of nurses' productivity, (21\%) had a moderate level of nurses' productivity and $(2 \%)$ had a high level of nurses' productivity.

Table(1):Social characteristics of the studied nurses $(n=30)$ 
The relationship between organizational justice and nurses' productivity at Menoufia University Hospitals

\begin{tabular}{|c|c|c|}
\hline Items & $\begin{array}{c}\text { No } \\
(n=300)\end{array}$ & $\%$ \\
\hline \multicolumn{3}{|l|}{ Age group } \\
\hline $20-30$ & 154 & 51.33 \\
\hline $30-40$ & 98 & 32.6 \\
\hline $40-50$ & 39 & 13.0 \\
\hline$>50$ & 9 & 3.0 \\
\hline \multicolumn{3}{|l|}{ Department } \\
\hline General & 155 & 51.7 \\
\hline Closed & 145 & 48.3 \\
\hline \multicolumn{3}{|l|}{ Gender } \\
\hline Male & 80 & 26.7 \\
\hline Female & 220 & 73.3 \\
\hline \multicolumn{3}{|l|}{ Marital status } \\
\hline Married & 250 & 83.3 \\
\hline Single & 50 & 16.7 \\
\hline \multicolumn{3}{|l|}{ Years of experience } \\
\hline $1-5$ & 95 & 31.7 \\
\hline $5-10$ & 55 & 18.3 \\
\hline $10-15$ & 80 & 26.7 \\
\hline$>15$ & 70 & 23.3 \\
\hline \multicolumn{3}{|l|}{ Qualification } \\
\hline Nursing school diploma degree & 61 & 20.3 \\
\hline Associated degree in nursing & 139 & 46.3 \\
\hline Bachelor degree in nursing & 78 & 26.0 \\
\hline Post graduate degree in nursing & 22 & 7.4 \\
\hline
\end{tabular}

Table (2): Mean score of organizational justice (Distributive justice, Procedural justice, and interactional justice) $(n=300)$ :

\begin{tabular}{||l|c|c|c|c|c|}
\hline \multicolumn{1}{|c|}{ Items } & Mean & $\begin{array}{c}\text { Std. } \\
\text { Deviation }\end{array}$ & Mini score & Max score & Mean\% \\
\hline Distributive Justice & 12.02 & 3.62 & 5 & 25 & $48.08 \%$ \\
\hline Procedural Justice & 14.49 & 3.67 & 6 & 30 & $48.3 \%$ \\
\hline Interactional justice & 22.13 & 6.33 & 9 & 45 & $49.18 \%$ \\
\hline Grand mean of organizational justice & 48.64 & 10.80 & 20 & 100 & $48.64 \%$ \\
\hline
\end{tabular}

Table (3): Distribution of the studied nurses regarding the achievement of productivity $(\mathbf{n}=300)$ :

\begin{tabular}{|l|c|c|c|}
\hline \multirow{2}{*}{ Items } & & No & $\%$ \\
\hline \multirow{2}{*}{ 1-Goal attainment } & No & 230 & 76.7 \\
\cline { 2 - 4 } & Yes & 70 & 23.3 \\
\hline \multirow{2}{*}{ 2-Work condition } & No & 235 & 78.3 \\
\cline { 2 - 4 } & Yes & 65 & 21.7 \\
\hline \multirow{2}{*}{ 3-Work engagement } & No & 87 & 29.0 \\
\cline { 2 - 4 } & Yes & 213 & 71.0 \\
\hline \multirow{2}{*}{ 4-Work motivation } & No & 235 & 78.3 \\
\cline { 2 - 4 } & Yes & 65 & 21.7 \\
\hline 5-Work organization & No & 134 & 44.7 \\
\hline
\end{tabular}


The relationship between organizational justice and nurses' productivity at Menoufia University Hospitals

\begin{tabular}{|c|c|c|c|}
\hline & Yes & 166 & 55.3 \\
\hline \multirow{2}{*}{ 6-Equipment and Supplies } & No & 241 & 80.3 \\
\hline & Yes & 59 & 19.6 \\
\hline \multirow{2}{*}{ 7-Quality of nursing services } & No & 209 & 69.7 \\
\hline & Yes & 91 & 30.3 \\
\hline \multirow{2}{*}{ 8-Nurse growth } & No & 189 & 63.0 \\
\hline & Yes & 111 & 37.0 \\
\hline \multirow{2}{*}{ 9- Decision making and Problem-solving } & No & 205 & 68.3 \\
\hline & Yes & 95 & 31.6 \\
\hline \multirow{2}{*}{ 10-Social relations } & No & 61 & 20.3 \\
\hline & Yes & 239 & 79.7 \\
\hline \multirow{2}{*}{ 11-Sick leave } & No & 174 & 58.0 \\
\hline & Yes & 126 & 42.0 \\
\hline \multirow{2}{*}{ 12-Work effectiveness } & No & 97 & 32.3 \\
\hline & Yes & 203 & 67.6 \\
\hline \multirow{2}{*}{ 13-Development and Advancement } & No & 222 & 74.0 \\
\hline & Yes & 78 & 26.0 \\
\hline \multirow{2}{*}{ 14-Physical work environment } & No & 190 & 63.3 \\
\hline & Yes & 110 & 36.7 \\
\hline \multirow{2}{*}{ 15-Wastes disposal } & No & 31 & 10.3 \\
\hline & Yes & 269 & 89.7 \\
\hline \multirow{2}{*}{ 16-Initiative } & No & 215 & 71.7 \\
\hline & Yes & 85 & 28.3 \\
\hline \multirow{2}{*}{ 17-New skills } & No & 89 & 29.7 \\
\hline & Yes & 211 & 70.4 \\
\hline \multirow{2}{*}{ 18-Work habits } & No & 79 & 26.3 \\
\hline & Yes & 221 & 73.7 \\
\hline
\end{tabular}

Table (4): Correlation among Distributive, Procedural, Interactional justice and Nurses productivity $(n=300)$

\begin{tabular}{|c|c|c|c|c|c|}
\hline \multicolumn{2}{|c|}{ Items } & \multirow{2}{*}{$\begin{array}{c}\begin{array}{c}\text { Distributive } \\
\text { Justice }\end{array} \\
1\end{array}$} & \multirow[t]{2}{*}{$\begin{array}{l}\text { Procedural } \\
\text { Justice }\end{array}$} & \multirow[t]{2}{*}{$\begin{array}{c}\text { Interactional } \\
\text { justice }\end{array}$} & \multirow[t]{2}{*}{$\begin{array}{c}\text { Nurses } \\
\text { Productivity }\end{array}$} \\
\hline \multirow{2}{*}{ Distributive Justice } & $\mathbf{R}$ & & & & \\
\hline & p-value & & & & \\
\hline \multirow{2}{*}{ Procedural Justice } & $\mathbf{R}$ & $.591^{* *}$ & 1 & & \\
\hline & p-value & .000 & & & \\
\hline \multirow{2}{*}{ Interactional justice } & $\mathbf{R}$ & $.208^{* *}$ & $.532^{* *}$ & 1 & \\
\hline & p-value & .000 & .000 & & \\
\hline \multirow{2}{*}{ Nurses productivity } & $\mathbf{R}$ & $.168^{* *}$ & $.198^{* * *}$ & $.221^{* *}$ & 1 \\
\hline & p-value & .003 & .001 & .000 & \\
\hline
\end{tabular}

**. Correlation is significant at the 0.01 level (2-tailed). 
The relationship between organizational justice and nurses' productivity at Menoufia University Hospitals

Table (5): Pearson Correlation between Total score of organizational justice and Nurses' productivity $(\mathbf{n}=\mathbf{3 0 0})$ :

\begin{tabular}{|l|c|c|}
\hline \multirow{2}{*}{\multicolumn{1}{|c|}{ Items }} & \multicolumn{2}{|c|}{ Nurses productivity } \\
\cline { 2 - 3 } & $\mathbf{R}$ & P -value \\
\hline Total score of justice & $.253^{* *}$ & .000 \\
\hline
\end{tabular}

**. Correlation is significant at the 0.01 level (2-tailed).

Table (6): Predicting the relationship between organizational Justice and Nurses' productivity $(\mathbf{n = 3 0 0})$ :

ANOVA

\begin{tabular}{|c|c|c|c|c|c|}
\hline Model & Sum of Squares & Df & Mean Square & F & Sig. \\
\hline Regression & 1273.727 & 1 & 1273.727 & 15.372 & $.000^{\mathrm{a}}$ \\
\hline Residual & 24691.670 & 298 & 82.858 & & \\
\hline Total & 25965.397 & 299 & & & \\
\hline
\end{tabular}

a. Predictors: (interactional justice, procedural justice distributive justice)

b. Dependent variable: nurses 'productivity

\section{Coefficients}

\begin{tabular}{|c|c|c|c|c|c|}
\hline \multirow{2}{*}{ Model } & \multicolumn{2}{|l|}{ Unstandardized Coefficients } & \multicolumn{2}{c|}{$\begin{array}{c}\text { Standardized } \\
\text { Coefficients }\end{array}$} & Sig. \\
\cline { 2 - 5 } & $\mathrm{B}$ & Std. Error & Beta & \\
\hline (Constant) & 32.929 & 1.845 & & 2.948 & .003 \\
\hline Distributive Justice & .433 & .147 & .168 & 3.478 & .001 \\
\hline Procedural Justice & .501 & .144 & .198 & 3.921 & .000 \\
\hline interactional justice & .326 & .083 & .221 & & .000 \\
\hline
\end{tabular}

a. Dependent Variable: nurses' productivity

\section{Discussion}

Organizational justice is one of the essential factors in existing and supporting the development of the organization and its staff (Mohamed, et al., 2018). Concerning aspects of justice, the current study presented that, the highest mean percentage of studied nurses toward organizational justice was related to interactional justice, while the lowest mean percentage was related to distributive justice .

From the investigator's perspective, interactional justice was limited by reduced information sharing with, and 


\section{The relationship between organizational justice and nurses' productivity at Menoufia University Hospitals}

lack of respect for subordinates, by supervisors among all professional subgroups .

This result was congruent with Metwally, et al., (2018). They reported that the mean percentage of interactional justice of nurses was highest among the three aspects of organizational justice .

Rajabi, et al., (2017) agreed with this study. They reported that the mean percentage of interactional justice is more than the mean percentage of procedural justice and distributive justice

On the other hand, the current results were inconsistent with Kamel, et al., (2019). They stated that the highest mean percentage of staff nurses' perception toward organizational justice was related to distributive justice. The lowest mean scores were related to interactional justice.

Regarding organizational justice, the present study results showed that the majority of the studied nurses had a low level of organizational justice. From the investigator's perspective, this may be due to the perception by all staff nurses that salaries, promotional opportunities, and hospital resources are generally insufficient. Inadequate pay and hospital resources have been reasons for industrial actions .

Silva \& Caetano, (2014) agreed with this study. They asserted that a lower level of organizational justice is related to negative effects such as stress, poor employees' psychological well-being, employee turnover, retaliatory intentions, etc.

The present study was also not matched with Akbolat et al., (2015), as they reported that the outcomes show that the organizational resources were distributed fairly and positive relations established with the employees during the distribution of resources. Chegini, et al, (2019) disagreed with the present study and reported that there was a higher level of organizational justice among nurses.

The result of the present study was revealed that there was a significant positive relationship between organizational justice and nurse' productivity. Doulati and Pour (2013), Mohamed (2014) agreed with this result and showed that a significant positive relationship between organizational justice aspects and productivity.

This result was congruent with Moosa, (2014). He reported that a positive relationship between organizational justice and its dimensions (distributive justice, procedural justice, informational justice) and productivity .

Salah, (2015) supports the present study result. He asserted that a positive relationship for the organizational justice dimensions (distributive justice, procedural justice, interactional justice, evolutional justice) on worker productivity.

This result was supported by Beverborg, et al., (2017), and Sadeghi, et al., (2013). They revealed that fair procedures and information sharing are a useful tool in making employees enjoy their work and improving their productivity. Also, Ogwuche, et al., (2018), and Krishnan, et al., (2018) agreed with this result. They reported that organizational justice associated with productivity.

This result was a contrast with kalay (2016). His study showed that among the aspects of organizational justice the only significant determinant of performance and productivity was distributive justice. Moreover, this study showed that 


\section{The relationship between organizational justice and nurses' productivity at Menoufia University Hospitals}

organizational justice was a predictor of nurses' productivity.

The Current study further revealed that there was a significant positive relationship between procedural justice and nurses' productivity. It might have been caused by the presence of nurses' voices during the decision making processes and their ability to challenge or appeal against the decisions arrived at by the institution. This result was in the same line with Kalay (2016) who found that procedural justice was a predictor of employee productivity.

The findings of this study also revealed that there was a significant positive relationship existed between interactional justice and nurses' productivity. Interactional justice focused on the interpersonal side of organizational practices, specifically, the interpersonal communication by management to their staff. Aboagye, (2015) agreed with this study. They asserted that both the direct supervisor and the organization can influence procedural and interactional justice depending on whether the measure's focus was on the organization or the supervisor.

\section{Conclusions}

In the light of the present study results, it can be concluded that:

The present study results revealed that more than half of the studied nurses had a low level of organizational justice; also three quarter of the studied nurses had low level of nurses' productivity

There was a highly positive statistically significant correlation between organizational justice and nurses' productivity.

\section{Recommendations}

1. Foster the development of a close relationship between nurse managers and nurses.

2. Encourage nurse managers to use a free flow of information, trust to nurses, open and two ways communication to improve interactional justice

3. The head nurse should set nursing care standard, evaluate nursing care, organize resources, plan the educational experience of nursing students, council staff as appropriate.

4. Productivity should be periodically measured to monitor the performance of nurses.

5. Conducting continuing education programs (training courses) for nurse manager about: management functions (clinical, managerial, professional skills) and how it can be used to empower subordinates to increase productivity.

6. Replication the study is needed with larger samples and different healthcare setting.

\section{References}

Aboagye, E. S. (2015). A Study of the Dimensions of Organisational Justice Which Best Predict Employee Trust and Productivity in Ghanaian Higher Education Institutions (Doctoral dissertation, University of Ghana).

Ajala, E. M. (2015). The influence of organisational justice on employees' commitment in manufacturing firms in Oyo State, Nigeria: Implications for industrial social work. African 


\section{The relationship between organizational justice and nurses' productivity at Menoufia University Hospitals}

Journal of Social Work; 5(1): 92130.

Al-Zu'bi, H. A. (2010). A study of relationship between organizational justice and job satisfaction.International. Journal of Business and Management; 5(12): 102.

Awases, M. H., Bezuidenhout, M. C., \& Roos, J. H. (2013). Factors affecting the performance of professional nurses in Namibia. Curationis; 36(1): 1-8

Azizollah, A., Hajipour, R., \& Mahdi, S. (2014). The correlation between justice and organizational citizenship behavior and organizational identity among nurses. Global journal of health science; 6(6): 252.

Beverborg A., Sleegers P., Endedijk M., van Veen K. (2017) Towards Sustaining Levels of Reflective Learning: How Do Transformational Leadership, Task Interdependence, and Self-Efficacy Shape Teacher Learning in Schools? In How School Leaders Contribute to Student Success, 23: 93-129.

Crawshaw, J. R., Cropanzano, R., Bell, C. M., \& Nadisic, T. (2013). Organizational justice: New insights from behavioural ethics. Human Relations; 66(7): 885-904.

Davis, V. (2015).The impact of perceived over qualification on the relationship between organizational justice and organizational citizenship behavior. Webster University.

Demirkiran, M., Taskaya, S., \&Dinc, M. (2016).A study on the relationship between organizational justice and organizational Citizenship Behavior in Hospitals.Int. J. Bus. Manage. Econ. Res; 7: 547-54.

Farhadi, P., Ravangard, R., Sajjadnia, Z., Jafari, A., Ghasemi, H., \& Rahgoshay, I. (2013). Study of factors affecting the productivity of nurses based on the achieve model and prioritizing them using analytic hierarchy process technique. Archives of Pharmacy Practice; 4(2): 63-71

Kalay, F. (2016). The impact of organizational justice on employee performance: A survey in Turkey and Turkish context. International Journal of Human Resource Studies, 6(1), 1-20.

Krishnan, R., Loon, K. W., \&Yunus, N. A. (2018).Examining the Relationship between Organizational Justice and Job Performance.International Journal of Academic Research in Business and Social Sciences; 8(3): 466-77.

Mahmoud, A. S. (2017). Psychiatric Nurses' Attitude and Practice toward Physical Restraint. Archives of psychiatric nursing, 31(1), 2-7.

McNesse Smith, D (1996). Increasing nurse productivity, job satisfaction and organizational commitment. Hospital service administration; 41(2):160-75. 


\section{The relationship between organizational justice and nurses' productivity at Menoufia University Hospitals}

Mengstie, M. M. (2020). Prceieved organizational justice and turnover intention among hospital healthcare workers. BMC psychology;8(1): 111

Metwally, G., Ata, A., \& Ahmed, K. (2018). Organizational Justice, Organizational Citizenship Behavior and Turnover Intention among Nurses: The Mediating Effect of Transformational Leadership. American Journal of Nursing; 6(6): 576-85.

Mohamed, H. A., Higazee, M. Z. A., \&Goda, S. (2018). Organizational Justice and Workplace Bullying: The Experience of Nurses. American Journal of Nursing, 6(4), 208-213.

Mooosa, H. (2014). Cultural differences in distributive and procedural justice: Does a two-factor model fit for Hong Kong employees? International Journal of Cross Cultural Management; 7(1): 61-76

Niehoff, B. P., \& Moorman, R. H. (1993). Justice as a mediator of the relationship between methods of monitoring and organizational citizenship behavior. Academy of Management journal; 36(3): 52756.

Rashed, S., Al Torky, M. , \&Morsey, S. (2015).Performance of Head Nurses Management Functions and It's Effect on Nurses' Productivity at Assiut University Hospital. IOSR Journal of Nursing and Health Science; 38-49.
Sadeghi, Musavi,\& Behrooz, (2013). Developing Human Resource Productivity through Organisational Justice. Journal of Public Administration and Governance, 3 (2), 173-190

Salah, S. (2015). The Role of organizational commitment in mediating the relationship between perceived organizational justice and job performance. European Journal of Social Sciences, 30(1), 125-135.

Suliman, A., \& Al Kathairi, M. (2013). Organizational justice, commitment and performance in developing countries. Employee Relations. 35(1), 98-115

Suliman, M., Aloush, S., \& AlAwamreh, K. (2017). Knowledge, attitude and practice of intensive care unit nurses about physical restraint. Nursing in critical care; 22(5): 264-269.

Younis, G. A., \& Sayed Ahmed, S. E. (2017). Physical Restraint and Maintenance of critically ill patient's safety in Intensive Care Unit: Effect of Clinical practice guidelines on nurse's practice and attitude. Nurs Health Sci; 6: 6-21.

Zoschak, E. (2010). 10 Indicators of Excellent Nursing Care. [online] Trusteemag.com. Available at: https://www.trusteemag.com/articles 609-indicators-of-excellent-nursingcare [Accessed 10 Nov. 2019]. 